\title{
Stakeholders Perspective On Alert Village Preparedness In Ngronggo Village Kediri City
}

\author{
Yeni Muslicha Dwi Rahayu, \\ Setyo Budi Susanto \\ Department of Public Health, \\ Institute of Health Sciences Strada \\ Indonesia \\ Email: \\ yeni.mdr@gmail.com
}

Received: October 5, 2020

Accepted : November 27, 2020

Published : November 30, 2020

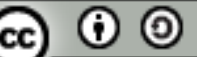

This is an open-acces article distributed under the terms of the Creative Commons Attribution-ShareAlike 4.0 International License.

\section{INTRODUCTION}

Development programs is of particular concern in many developing countries in Southeast Asia, is no exception with the Indonesian state. Development programs are not only seen from a concrete economic or physical point of view, but development in the health sector is included in programs that need special attention. Development is a process of
Village / Alert Village is a picture of a community that is aware, willing and able to prevent and overcome various health problems that occur in the community. This research was conducted in Ngronggo Subdistrict, Kota Kediri Subdistrict, because the Kelurahan already has and runs a Kelurahan Health Center (Poskeskel). Lack of understanding related to the duties and functions related to the alert villages, especially to the stakeholders, has not yet dropped the latest regulations from the local government which underlie and regulate the development of the active alert villages. This study aims to explore the readiness of stakeholders in the active alert village program in terms of knowledge, roles and constraints on the standby village program in Ngronggo village. This research uses descriptive qualitative research method with purposive sampling because it is inductive and the results emphasize more meaning. Results: Active alert kelurahan are characterized by having a poskeskel (kelurahan health center) as a marker for the establishment or readiness of the kelurahan in improving public health. The geographical location of the poskeskel is evidence that the government, in this case, Ngronggo Village cares about the health status of its people. The cadre as an arm of the Ngronggo Village was able to provide education to the public about preventing an illness. The administration system is currently in the process of repairing and reworking so that the poskeskel function can be realized as a data bank. Village as the owner of the area also has an important role in the selection of resources. The puskesmas was able to advocate these regulations so as to clarify the tasks and roles of each individual involved in active alert kelurahan activities in Kelurahan Ngronggo.

Keywords: Active alert, preparedness, stakeholder

Copyright $@ 2020$ IIK STRADA Indonesia All right reserved. 
communication or delivery of intentions or messages carried out by a person or group in order to change a person's attitude, behavior or opinion to achieve better reform.

The delivery of health services to the community at the primary level in Indonesia is through the Community Health Center (PUSKESMAS) which is a functional organizational unit of the District/Municipality Health Office and is given responsibility as a health manager for the community in each sub-district region of the relevant regency/municipality. The Southern District Health Center in the City District of Kediri City is a health service unit located in the middle of the city and easily accessible compared to other health units. One program that is being promoted to achieve the degree of public health is through the Government's policy on "Alert Village" (Guidelines for Desa and Kelurahan Active Siaga according to the Decree of the Minister of Health of the Republic of Indonesia Number 1592 / Menkes / SK / X / 2010).

This research was conducted in Ngronggo Subdistrict, Kota Kediri Subdistrict because the Kelurahan already has and runs an Kelurahan Health Center (Poskeskel), and has a superior program in the health sector including WPA (Citizens concerned with AIDS), PPA (Protection of Women and Children), and Kelurahan BERSINAR (Drug Narcotics).

So based on a preliminary study of researchers on October 2 in Ngronggo kelurahan, representatives of the standby village cadres, and program holders at the puskesmas, information was obtained that the standby village program already exists and runs under the name active active kelurahan in the middle category but not yet working as it should mainly in the section administration as in the case of reporting due to lack of understanding related to the main tasks and functions related to the standby village, especially for stakeholders including the kelurahan government and cadres, the latest regulations from the local government that have not been based on and regulate development in the village or kelurahan are active so that it can be said to be dead. The standby village program. So from this the researcher wants to deepen and explore the research especially on the readiness of stakeholders in the alert villages in Ngronggo. As well as obstacles those occur in the implementation of the standby village. This study aims to explore the readiness of stakeholders in the active alert village program seen from the knowledge, roles and constraints of the standby village program in the Ngronggo village.

\section{MATERIALS AND METHODS}

Researchers used descriptive qualitative research methods because this study explored the views or perspectives of stakeholders in the readiness of the active standby village program in the Ngronggo village, Kediri City. Besides this research is also inductive and the results emphasize more meaning. The use of purposive sampling in this study is aimed at being able to explore how knowledge, roles, and constraints that occur by stakeholders in the readiness of active standby villages in Ngronggo, Kediri City.

\section{RESULTS}

This research activity was carried out in Ngronggo Village, Kota Kediri District, East Java Province. Ngronggo village has an area of 330 hectares, with longitude coordinates: 112.026554, latitude coordinates: -7.842926 and altitude above sea level: 120 meters which are divided into 9 RWs consisting of $71 \mathrm{RT}$.

Judging from the characteristics of the sex it is found that there are 6 male informants and 5 female informants. From the age characteristics, it is obtained the data of informants aged between 30-35 years are 2 people, while those aged 36-40 years are 2 people and those 41 years or more are 7 people. The length of office of the informant is very diverse, the informants who have served 1-5 years are 8 people, the length of office of 6-10 years is 1 person, and more than 10 years are 3 people. The researchers' data were obtained from February to March 2020 with Stakeholder informants 
consisting of pillars of the kelurahan, representatives from the municipal health centers in the southern region, as well as representatives from active standby village cadres.

\section{A. Knowledge of Active Alert Village}

Some of the informants also said that the active alert kelurahan is a village that is responsive in health with its own community resources who are able to overcome health problems with easy access. As the following informant statement:

"Okay, the village wanted by the local government in this case the government of the City of Kediri so that this village is active in everything from the aspect of security, order, from the aspect of health or government and optimal services and especially the empowerment of human resources in the village "(L4-informant 2)

Informants who describe the benefits of active standby families are able to help the community in reducing the burden to achieve health status as the following informant statement "If I do in general yes we just help the community to improve their health status "(L4-informant 7).

The development target of the active alert village program an informant explains that the development target of the active standby village program constitutes the whole society in Ngronggo Kelurahan as the informant said below:

"For the purpose of developing the standby villages that I have followed so far, there are residents, then there are facilities and infrastructure that are always adequate and they always follow the developments and they also always improve the ability of our citizens who are members of the rapid reaction team "(L6-informant 4).

The order of reporting activities carried out by health cadres as obtained information that some informants said there was reporting from cadres in each agenda carried out which was then submitted to the kelurahan. The existence of warning signs in the preparation and construction stages as one of the educational steps for residents which works closely with related agencies. There were also some informants who stated that there were no warning signs as conveyed by the following informants:

"As in Ngronggo, so far there have not been any warning signs such as those in the village of Ringinom not there" (L12-informant 3).

This is supported by the triangulation statement that never knew for Ngronggo, which certainly exists in the Manisrenggo area with disaster-prone areas and gathering point signs. As the following statement:

"Hopefully I'm wrong how come it seems like I never knew that clearly knew that if in Manisrenggo it was clear if I wanted to see it every time I turned it was the direction of the evacuation of the flood so there was made for example there was a flood-prone there was written in this direction the direction of the evacuation at eventually there will be a point kumpulnya so LHA so far not been there "(Source L 26)

B. Roles in Village active standby

Role of the office in implementing programs for urban active standby say that coordinating joint activities proposal for development on the agenda musrembang and prodamastentang facilities and infrastructures in particular in terms of health, as referred to by the following informant:

"Coordinate with the health center and village if there are problems in particular problems health that occur in the community "(L54-informant 9).

There is also an assistance to improve public health with several activities, such as the statement of the following informant: 
"The role is to improve health by implementing activities at toddlers' posyandu, elderly posyandu, at posbindu, and carrying out these outreach activities and there are even aaaaa house-to-house visits ranging from toddlers, pregnant women, and elderly health" (L26-informant 8).

Some of the programs include conducting UKBM, PHBS, MCH, mental, and several surveys. As explained by the following informant:

"For the time being, there is a program in Ngronggo Kelurahan that improves posyandu and then health, especially for children under five for pregnant women and then for parents who at any time clearly need help either during the day or at night "(L16-informant 4).

Unlike the case with information that explains that there is less attention related to programs running in active alert villages, as follows:

"Go directly to the chairman if my programs are lacking "(L28-informant 10)

Steps in program development villages active standby is to perform coordination between health workers, community health centers, as well as the village related health information of citizens, as an interviewee the following:

"the development that has been taken by the urban village setting up facilities and infrastructure both suggestions are as ambulance when -the time is ready to use then pe then take care of the village midwife at the puskesmas or at the puskesmas at ngronggo "(L20-informant 4)

Some of the activities that are followed and elaborated by informants include activities based on UKBM (Community-Based Health Efforts), $\mathrm{MCH}$, and activities survey health door-to-door. As the following informant's statement:

"The alert village in our posyandu friends are present especially if in our toddlers' posyandu all RW have elderly posyandu which is not yet an active role of the alert cadre to form an elderly posyandu so the elderly also need an approach so that the health of the elderly is increasingly nurtured and awake. For example, if tomorrow there are citizens starting in 2020, all of them will be registered with BPJS insurance. We hope that there will be a name like the elderly posyandu in one of the RWs in RW 8, every month they will hold gymnastics by their watchdog after the exercise in their health checks, after there is an agenda to gather. Posyandu for the elderly can be more guarded for the elderly so that they become more enthusiastic about their lives "(L22-informant 1)

\section{Constraints in Active Alert Kelurahan}

The problem also appears in the lack of knowledge of citizens regarding health as the informant's statement follows:

" The constraints faced at Ngronggo for their knowledge let's have a healthy life that's lacking so sometimes there are many in that region like stop smoking it is also difficult to keep conscious to hmmm behave healthy life is also less like aaa the cleanliness of the house is also lacking "(L40informant 8)

But there are also informants who explain the problem lies in the performance of health cadres as follows:

"Kendal anya or aaa the continuation or consistency of the cadres means that they are less consistent so when there is a visit there is a new competition (gruduk) Simultaneously. But there are routinely certain that there are regular meetings to discuss issues, but (the spirit of being runny with contests, the feeling of going on review) Enthusiasm when there is a competition, there will be a review. There is a new spirit (Oyaki kabeh) Encouraged all"(L46-informant 5)

It is powered by source statement that explains the lack of ability of cadres who wait their race and it complements and data from health centers should poskeskel as a data bank has conversation own, as well as their equal distribution of cadres in each rw. The nature of social performance so that puskesmas depend on cadres as the following statement: 
"Enough should have an area that as a data bank so its nature should not be reversed so far because of the poskeskel the term is yo way. It's only possible for administration if the cadre is very difficult to be told like an office worker, while if there is any request, for example, if there is a competition or anything, the request must be at the puskesmas, they should have a data bank, they would know better, for example, data about aaa jumantik, whose house is free of larvae, what is the name of AJB? how many larvae are there? You don't have to wait for them to do it first, you should know there, like that, maybe in the future, all reports starting from this year will be disciplined that all good reports are weighing, poor nutrition, pregnant women, all must be deposited to the poskeskel In fact, if possible, the cadre chosen by Poskeskel will have a participant kilan out of all RWs or at least karo RWs Nine means that there is a minimum of RW 1,2,3 to 9 so later when asked the coordination is better for example if now the cadre is divided into two kilisuci and joyoboyo it should be delicious when asked AJB ooo RW 9, RW 9 later, who is a joyoboyo, please ask for this data, if it's still lazy to record, but this is going to be slow, what's important, actually, if it's active, it's active. Just to say, if people ask for proof, they always ask for black and white, right? because we work not with academics, if the cooperation between cadres is different they want to become a cadre. Thank God, thank God that they are actually working, they can, if they are diligent, then we immediately demand for administration, and so they are afraid to run away "(Source L22)

Some informants explained to overcome the existing problems in the form of coordination in routine inter-sectoral meetings as stated by the following informant:

"Now you want, you don't have monthly meetings, you don't have them, now we try routinely, we will later try to have cash so that later when there are activities for example yesterday there is a village fund activity that one of the activities of its implementation responsibility is LPMK, for example the rich fence-fence "(L34-informant 6)

Some informants also argued that in resolving problems can be done by visiting residents' home by providing health education.

\section{DISCUSSION}

A. Knowledge Active Active Alert Village Active Alert

Village is an effort to empower the health of the government so that people are willing and able to live healthy independently. The role of Community Empowerment Cadres is found in Permendagri Regulation No.7 of 2007, namely Community Empowerment Cadres, which is then abbreviated as KPM, namely members of the Village or Village community who have the knowledge, willingness and ability to mobilize and encourage the community to participate in community empowerment and participatory development.

As for my view, what I see is that active alert villages are an effort to improve the degree of public health that is responsive to the health of the community as one of the prevention efforts in the family and ease in accessing the health of its citizens, especially in Ngronggo Village, able to be understood and interpreted well by each individual who in terms of this is the policy maker in the Ngronggo Village administration and its health cadres. Cadre as an arm of the Ngronggo Village is able to provide education to the community about prevention of a disease that starts from within the family which can be monitored one of them in the PHBS survey (Clean and Healthy Behavior) as well as several other activities such as posyandu and routine immunizations done. Ease of access to health services obtained by the people of Ngronggo Urban Village is one of the proofs of active active urban villages, the geographical location of the poskeskel is one of the government's evidences, in this case Ngronggo Urban Village cares about the health status of the community.

Reporting is evidence that the active alert village program is running. Reporting here includes the administration system in the active alert kelurahan in Ngronggo kelurahan and the reporting of activities carried out by active cadres in active kelurahan. The situation in the field explains that the 
administrative system is currently in the process of being repaired and reworked, with a new management and a new regulatory system as well.

The meaning of the existence of active alert kelurahan which means that citizens are able to do a level of prevention that starts from the family. Disaster warning signs are an effort in terms of preventing risks and hazards that can cause health problems (disasters, epidemics, emergencies and so on). The existence of natural disaster warning signs can increase citizen education.

\section{B. Role in Active Alert Kelurahan}

The role of stakeholders is the spearhead of the sustainability of the alert kelurahan. From the stakeholders rules and job descriptions become clear so that there is no overlap in the field.

Community Empowerment Cadre (KPM) is a member of a village or kelurahan community who has the knowledge, willingness and ability to move the community to participate in community empowerment and participatory development in villages and villages. The development of an alert village is an effort to bring health services closer to the village community, to prepare the community to face health problems in developing clean and healthy behavior. The planning and budgeting mechanism is discussed through the Village Development Planning Consultation Forum (Musrenbangdes). Whereas activities in the framework of developing Active Alert Village are proposed through the City Development Planning Conference.

Community empowerment activities continue to be pursued through the development of UKBM in the village. The activity focused on community-based surveillance efforts, health emergencies and disaster management and environmental sanitation. Community-based surveillance is the observation and recording of diseases carried out by the community (cadres) assisted by health workers, based on technical guidance from the Ministry (2010), stated that health so that in this case it can be referred from the community by the community to that community as well.

With the existence of Poskesdes, the village in question can be established as Desa Siaga. After the Desa Siaga was officially formed, it was continued with the routine implementation of the Poskesdes activities, namely the development of community-based surveillance systems, the development of preparedness and emergency response and disasters, eradication of infectious diseases and diseases that could potentially cause outbreaks, fundraising, community empowerment towards KADARZI and PHBS, sanitation environment, and basic health services (if needed). In addition, UKBM-UKBM services are also held

\section{Constraints in Active Alert Village}

Each informant has a different classification. Like clarification on funding issues. One source of funding comes from the PRODAMAS program (Community Empowerment Program), where the program allocates around $20 \%$ for social activities. The management reshuffle in stakeholders has made some of them unable to participate in active standby village activities. This is also the background for the rise of the active alert village program which is expected to improve the degree of public health. On the other hand, the task for stakeholders is to continually increase the knowledge of their citizens, especially in terms of health so that at least they know the directions on clean and healthy behavior. This can be started with training conducted starting from health cadres as extension workers at the community level. The lack of training returned by the local government certainly has an impact on the ranks below.

All of the above are the tasks of all parties so that with good cooperation the active standby village program is able to run as it should, efforts and efforts to re-demonstrate the existence of the active standby village begin to be encouraged by the preparation of a new organizational structure, elaboration of the new job disk according decision of the regional secretary number: 188.4 / 370 / 
419.033 / 2020 about the health cadres of the City of Kediri which also explains the grouping of cadres who were once one is now grouped into kilisuci cadres that overshadow the IVA group, asthma toga, poskeskel, and tb pulmonary while for cadres who used to be one are now grouped into kilisuci cadres that overshadow the IVA group, asthma toga, poskeskel, and tb lung while for cadres who were once one incorporated in the joyoboyo cadre overshadowing jumantik, elderly posyandu, posyandu soul, echoes carefully. The purpose of holding village meetings or workshops is to find alternatives to solve the health problems resulting from SMD related to the potential of the village. In addition, it is also to draw up a long-term plan for the development of an alert village. The initiative for organizing a deliberation should come from community leaders who have agreed to support the development of an alert village. Participants in the deliberations are community leaders, including local women and youth leaders. Even as much as possible involved the business community who are willing to support the development of alert villages and their sustainability (advocacy efforts are needed).

Matters that can be implemented with non-governmental organizations and / or assistance from donors (for example private), are combined in a separate document. Whereas things that need Government support are included in the village Musrenbang documents to be forwarded to the Musrenbang.

The solution to the problems arising in the field was also carried out by visiting residents' homes as an effort to increase public knowledge about their primary health, informants said that people who were still ignorant in several activities such as attending the posyandu were still underestimated on the pretext of forgetting, there are jobs or other people present at the posyandu activities so that important information about health is not well conveyed, so that the puskesmas together with the cadres provide motivation and education to some of the community.

All of that requires a process in its application in the field so that it can be realized in accordance with the main tasks and functions and can provide focus to each cadre and become an additional task for the village administration in this case Ngronggo village in finding cadre resources for all these tasks to take place.

\section{CONCLUSION}

Cadre as an arm of the Ngronggo Village was able to provide education to the community about prevention of a disease that starts in the family as well as several other activities such as posyandu and immunizations that are routinely carried out. Ease of access to health services obtained by the people of Ngronggo Urban Village is one of the proofs of active active urban villages, the geographical location of the poskeskel is one of the government's evidences, in this case Ngronggo Urban Village cares about the health status of the community. The situation in the field explains that the administration system is currently in the process of being repaired and reworked, with a new management and a new regulatory system as well. The meaning of the existence of active alert kelurahan which means that citizens are able to do a level of prevention that starts from the family. Disaster warning signs are an effort in terms of preventing risks and hazards that can cause health problems (disasters, epidemics, emergencies and so on).

The Community Empowerment Cadre (KPM) in this case is the cadre of the standby village as an arm of the village party is a member of the village community or village who has the knowledge, willingness and ability to move the community to participate in community empowerment and participatory development in the village and kelurahan. The development of an alert village is an effort to bring health services closer to the village community, to prepare the community to face health problems in developing clean and healthy behavior. Therefore in the standby village there must be facilities or facilities for basic health services. 
Problems that arise include the lack of regulations governing the maintenance of equipment so that it becomes a polemic for residents who want to use the facilities as an example when the elderly Posyandu activities take place. The diversity of educational backgrounds of health cadres raises the level of difficulty in receiving instructions for carrying out their duties. Currently, cadres often wait in orders when doing work, where the role of the regional midwife as the coach has a large share. The lack of training returned by the local government certainly has an impact on the ranks below. The description of the new tupoksi is in accordance with the decision of the regional secretary number: 188.4 / 370 / 419.033 / 2020 concerning the health cadre of Kediri City.

The activity focused on community-based surveillance efforts, health emergencies and disaster management and environmental sanitation. The management reshuffle in stakeholders has made some of them unable to participate in active standby village activities. Resolution of problems that arise in the field can be done by visiting residents' homes as an effort to increase public knowledge about health. Strong relationships with stakeholders are based on trust, respect and cooperation.

\section{ACKNOWLEDGMENTS}

The author is thankful to respondents for their valuable information and their awareness to participate in this research.

\section{CONFLICTS OF INTEREST}

The author declares that they have no conflict of interest

\section{REFERENCES}

Ministry of Health of the Republic of Indonesia. (2010). General Guidelines for Active Desa and Kelurahan Development. Jakarta.

Decree of thesecretary regional number: 188.4/370/419,033/2020. (2020). About Kediri City Health Cadre. Kediri.

Mayor Regulations Kediri. (20017). The Fifth Amendment to Kediri Mayor Regulation Number 40 of 2014 concerning Guidelines for Implementing Community Empowerment Facilitation Programs. Kediri.

Runjati. (2010). Community Midwifery Care. Jakarta: EGC.

Sarlito Wirawan Sarwono. (2015). Theories of Social Psychology. Jakarta: Rajawali Press.

Sarwito Wirawan Sarwono. (2015). Theories of Social Psychology. Jakarta: Rajawali Press.

Satori, Djam'an \& Komariah Aan. (2011). Qualitative Research Methods. Bandung: Alfabeta.

Sugiman. (2018, July). Village Government. Suryadarma University Law Faculty, Vol. 7 No. 1.

Sugiono. (2012). Qualitative Quantitative Research Methods and R\&D. Bandung: Alfabeta.

Sukmadinata, Nana Syaodih. (2013). Educational Research Methods. Bandung: PT Youth Rosdakarya.

Totok Mardikanto, CRS (Corporate Social Responsibility). (2014). (Corporate social responsibility). Bandung: Alfabeta. 